\title{
A laboratory hive for frequent collection of honeybee eggs
}

\author{
SW Omholt 1, A Hagen 1, O Elmhold! 1, S Rishovd 2 \\ ${ }^{1}$ Agricultural University of Norway, Department of Animal Science, PO Box 5025, 1432 Ås; \\ 2 The Biotechnology Centre of Oslo, University of Oslo, PO Box 1125, Blindern, 0317 Oslo, Norway
}

(Received 2 November 1994; accepted 3 May 1995)

\begin{abstract}
Summary - We describe a hive design that allows frequent collection of eggs of a defined age with only slight disturbance of the worker bees or the queen. The hive may be operated in the bee yard or in a flight room, and has proven to provide a steady supply of eggs throughout the year. The eggs are placed on small wax-coated plastic cell bases serving as removable bottoms of normal worker cells and are collected without opening the hive. This also makes the eggs more accessible for laboratory manipulation compared to eggs deposited in ordinary frames.
\end{abstract}

honeybee / egg collection / laboratory hive / flight room / micromanipulation

\section{INTRODUCTION}

Considering the commercial importance of the honeybee, its use as a model for the study of insect societies and neurobiological issues, and the fact that the honeybee egg in itself is very amenable to laboratory manipulation (DuPraw, 1967), the scarcity of experimental work on eggs and embryos is somewhat surprising. There are certainly several reasons for this, but we think that the lack of a proper preparative system, ie management of bees, eggs, and larvae within a laboratory context in temperate regions, is a major part of the answer. Such a system includes access to a flight room for all year work, a method for collecting eggs from the hives without disturbing queens or worker bees, a simple method for successful incubation of honeybee eggs, and a simple method for in vitro production of honeybee workers. Negligible disturbance of the queen and the bees during egg collection is very important to maintain continuity of egg laying. In most cases, methods based on opening the hive during collection (eg, Schnetter, 1934; Rembold et al, 1992) will interrupt the egg-laying pattern. We have run such a preparative system for 3 years, partly by using available knowledge (Jay, 1964; Praagh, 1972, 1975; Doull, 1976; Rembold and Lackner, 1981; Peng et al, 1992), and partly by developing new proto- 
cols (Omholt et al, 1994). Here we report a new hive design that meets the requirements concerning easy egg collection, and which may be used in a flight room and in the bee yard.

\section{MATERIALS AND METHODS}

The egg collection hive consists of 2 sampling frames of almost the same size as a Norwegian standard frame ( $370 \times 255 \mathrm{~mm})$. Each frame is made from 6 Jenter frame bases (Karl Jenter, Nurtingen, Germany), ordinarily used as queen rearing equipment (fig $1 a, b)$. The cell sides of the frame bases are facing inwards, their rear sides making the outer surface of the hive. A hive body is made to accommodate the 2 sampling frames with a bee space of $12 \mathrm{~mm}$. The floorboard and the crown board are made of one layer of $12 \mathrm{~mm}$ plywood and the end walls of 2 layers. Bars measuring 42 by $17 \mathrm{~mm}$ connect the walls (fig $1 \mathrm{c}, \mathrm{d}, \mathrm{f}$ ).

The bees are offered pollen from a tray and sugar syrup from a vacuum jar placed in the flight room (fig $1 \mathrm{~h}$ ), but to make additional feeding possible, the crown board has 2 holes, one for a vacuum jar of sugar syrup, the other for giving pollen dough by an inverted $50 \mathrm{~mm}$ Petri-dish (fig 1f).

The 90 extractable cell bases made of plastic of the individual Jenter frames are mounted in holes in aluminium plates (collecting plates), $4 \mathrm{~mm}$ thick (fig 1a), exactly fitting the holes in the frames, which have to be drilled to $5 \mathrm{~mm}$ to allow for some unavoidable inaccuracy in construction. Eggs may be collected without disturbing the bees to any extent by removing a plate from the outside without opening the hive and replacing it with an empty one. A plate collected from the hive may be incubated as a whole, or one may incubate only the plastic bases containing eggs, which are neatly deposited on the plastic cell bases (fig 1g). Normally, only 2 plates are used for egg collection to allow production of as much brood as possible. The rears of the other Jenter frames are then covered by aluminium tape and insulated as well by squares of styrofoam (fig 1a, c). The crown board and the side walls may also be insulated (fig 1f, h). It should be stressed that only the basic unit of the Jenter frame and not the unit imitating cell walls, is used. A strong colony was allowed to complete the cells of the frames before they were used in the laboratory hives. Thus, for practical reasons, it is recommended to modify the dimensions of the sampling frame in accordance with dimensions of local production hives and frames.

The hive is hinged at the back side, so that inspections can be performed very easily by just opening it in front and gently pulling the 2 halves apart (fig 1e), and it is initially loaded with 2000 2500 bees.

Detailed drawings and construction details of the hive are available on request.

\section{RESULTS AND DISCUSSION}

The hive design reported here has been tested for 11 months in a flight room (fig $1 \mathrm{~h}$ ), and the hives have functioned very well (a very similar design has been used the 2 previous seasons). The colonies are most often capable of self-recruitment, but on a few occasions we have been forced to strengthen colonies during the winter season with bees taken from a normal colony in the bee yard. The size range of well-functioning colonies seems to be $1400-2500$ bees. During the season 1993-1994, 3 queens out of 10 died or stopped egg laying, and had to be replaced. The egg-laying rate on the collecting plates will of course vary somewhat, as the queen happens to be occupied with egg laying at other places in the hive. However, the mean number of eggs collected per hour per colony is rather fixed. As an example, table I shows egg collection data from 6 colonies (Apis mellifera) on July 6 and 7,1994 . The flight room had then been operated without interruption since September 1993, and the egg-laying rate had stayed at, or somewhat above, this level during the whole period. The reported egg-laying rate is sufficient for most purposes. If one needs more eggs, this may be obtained by harvesting more collecting plates. Table I shows data for collecting intervals as long as from 1.75 to $3 \mathrm{~h}$, and the inexactness of the age determination is of course in correspondence. However, if 

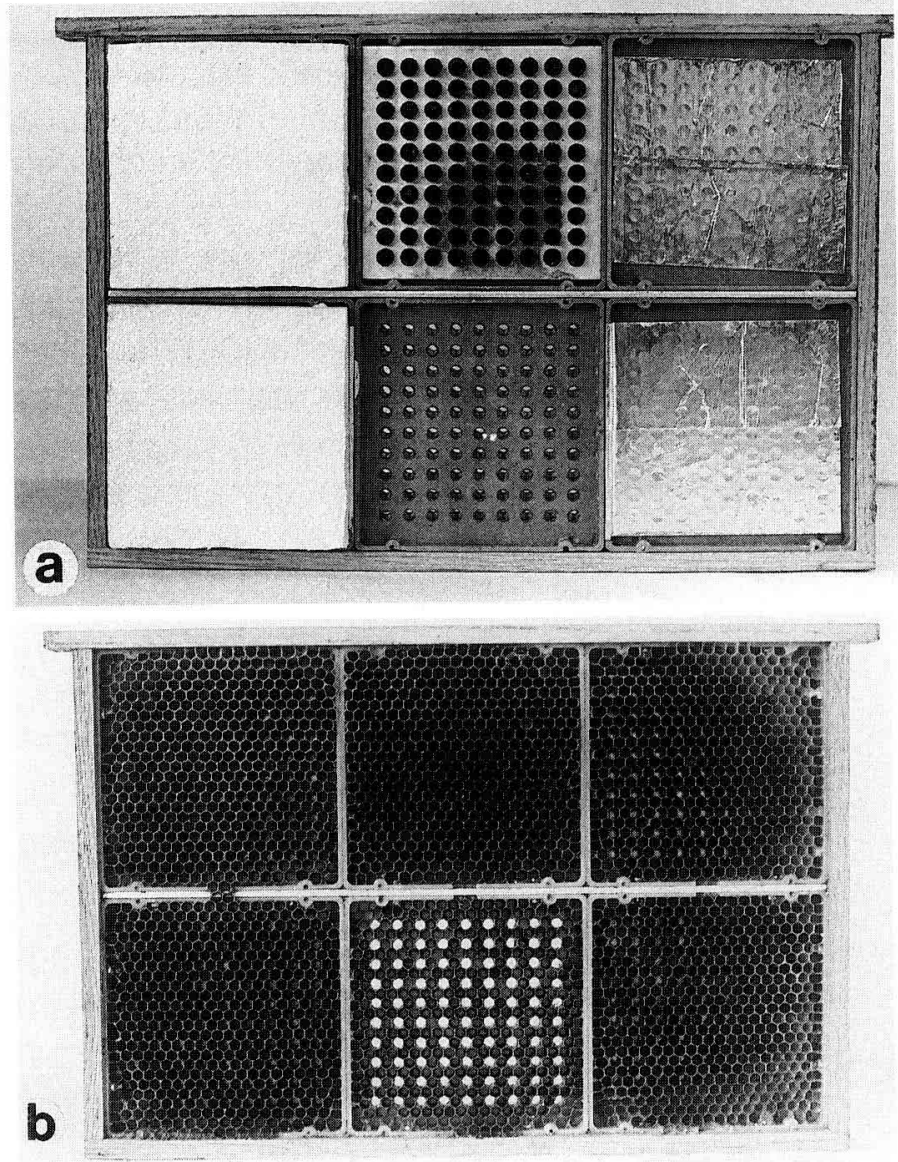

Fig 1a-c. The laboratory hive. (a) the frame made from 6 Jenter frame bases, rear view. Lower middle, a naked Jenter frame. Upper middle, a collecting plate holding the 90 cell bases. Right, frames not used for sampling covered by aluminium tape. Left, styropor insulation added. (b) The same viewed from the cell side. (c) Frame accommodated in hive body.

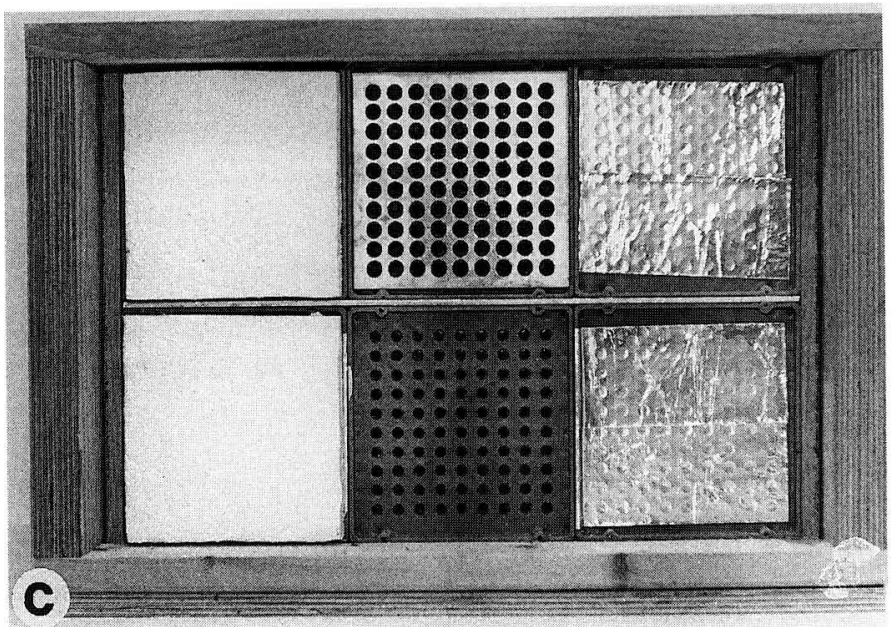


the sampling interval in this case is reduced to $15 \mathrm{~min}$, we would collect about 10 eggs per sampling of an age sufficiently exact for most scientific purposes.

When eggs are not to be sampled for some days, the eggs should be brushed off the plates daily. This serves as a control of the condition of the hive in addition to preventing the sampling area from being blocked by larvae and sealed brood.
In a certain period the area of egg laying is of course limited, and it is important to know which frames are actually used by the queen if the harvest is to be optimized. On the other hand, it is reasonable to believe that the egg-laying rate can be improved by using only young queens with a very high brood production, and by performing a selection programme among these.
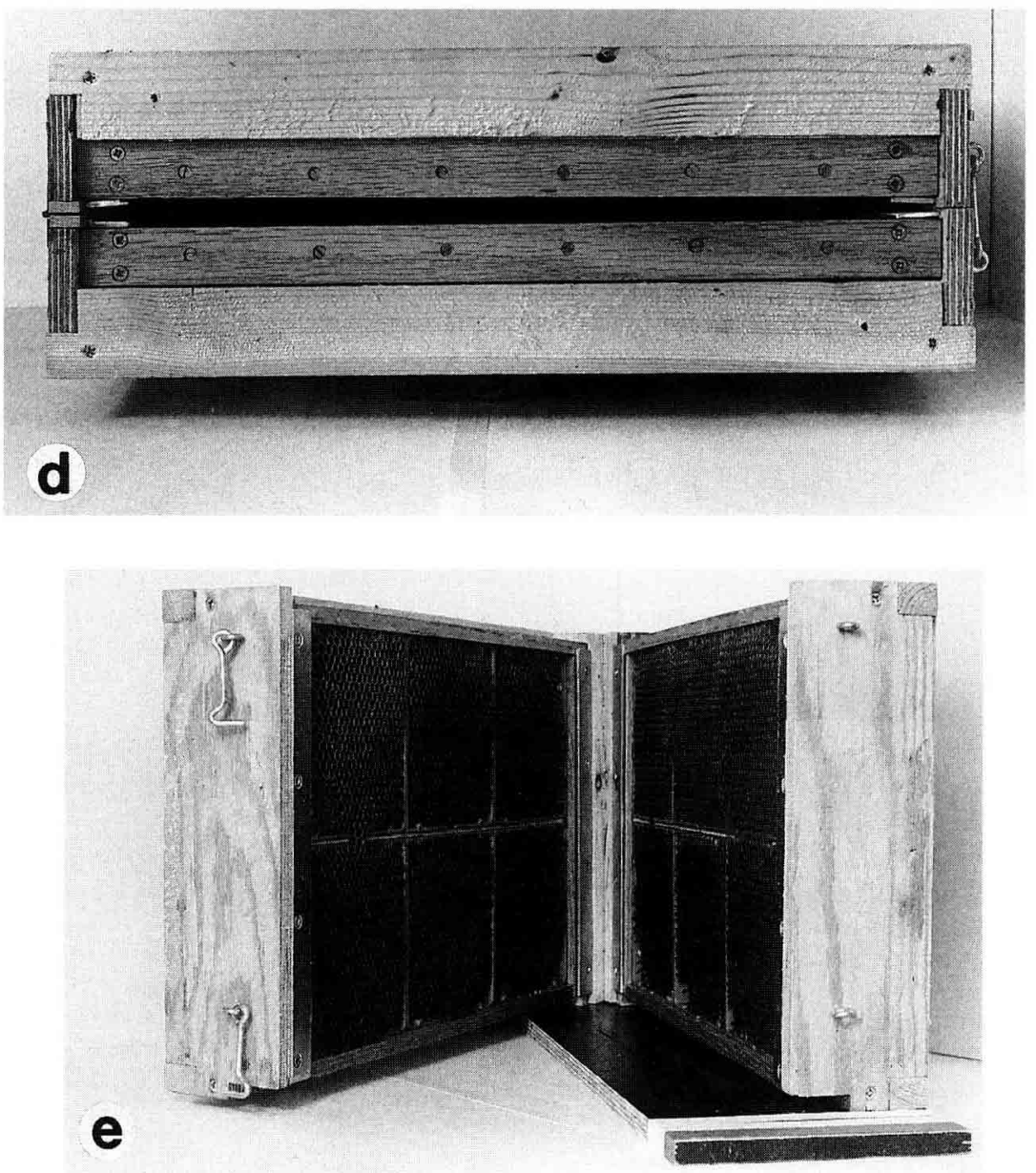

Fig 1d-e. The laboratory hive. (d) Top view of the hive, crown board removed, showing the 2 frames separated by a $12 \mathrm{~mm}$ bee space. (e) The hinged and the opened hive. 


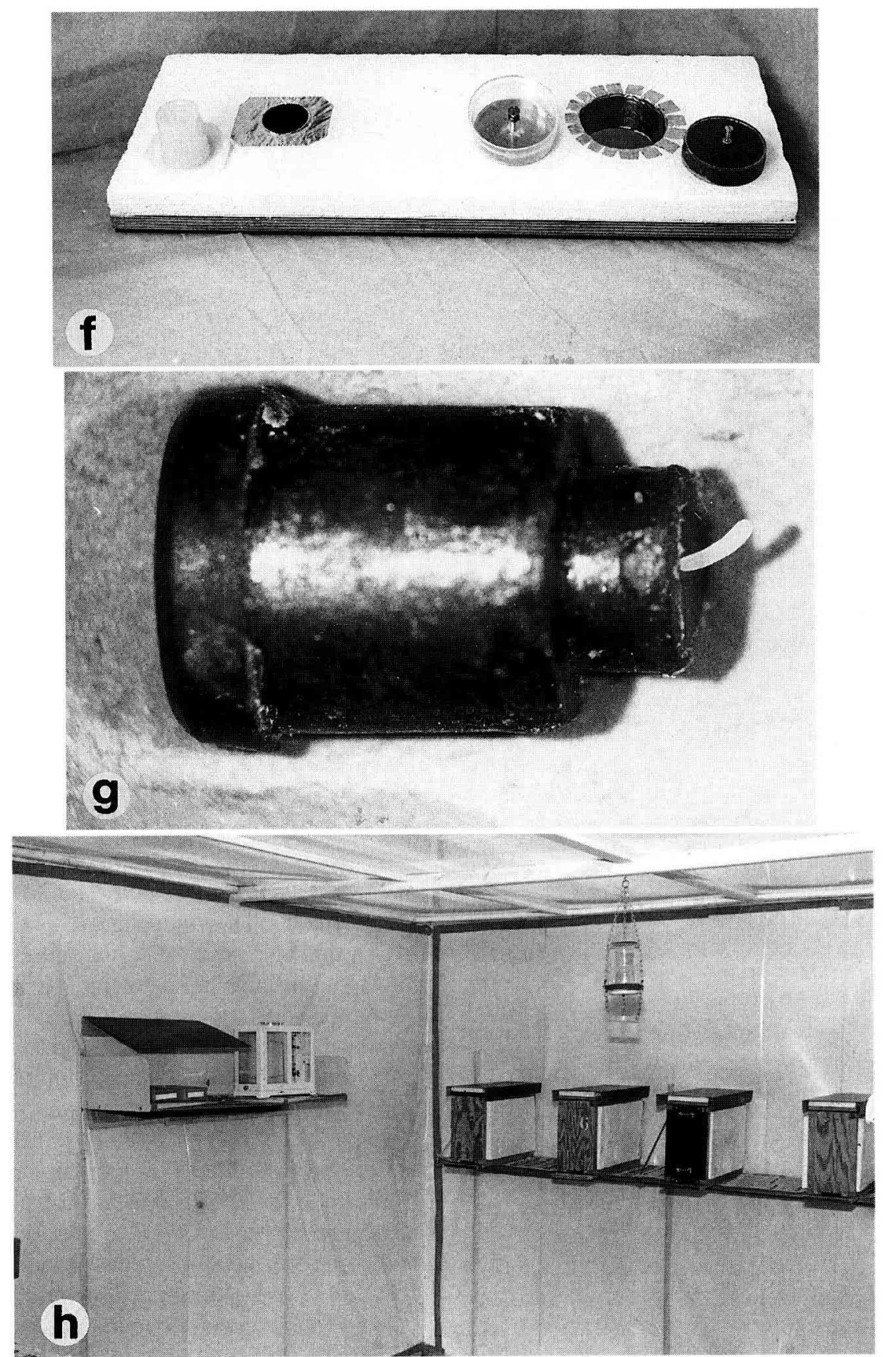

Fig 1f-h. The laboratory hive. (f) Insulated crown board with holes for feeding and their stoppers and a shafted Petri dish for pollen dough. (g) Plastic base with egg. (h) Sampling hives in the flight room. Pollen trays and vacuum jar for visible sugar syrup. 
Table I. Egg collection data for $2 \mathrm{~d}$ from 6 hives in a flight room using 2 collecting plates per hive.

\begin{tabular}{|c|c|c|c|c|c|c|c|c|}
\hline Hive & $\begin{array}{l}07.00 \\
(24 h)\end{array}$ & $\begin{array}{c}09.00 \\
(2 h)\end{array}$ & $\begin{array}{c}12.00 \\
(3 h)\end{array}$ & $\begin{array}{c}13.45 \\
(1.75 h)\end{array}$ & $\begin{array}{l}07.00 \\
(17 h)\end{array}$ & $\begin{array}{c}09.00 \\
(2 h)\end{array}$ & $\begin{array}{l}11.00 \\
(2 h)\end{array}$ & $\begin{array}{l}13.00 \\
(2 h)\end{array}$ \\
\hline 1 & 122 & 0 & 3 & 0 & 103 & 7 & 6 & 0 \\
\hline 2 & 113 & 5 & 30 & 21 & 163 & 15 & 16 & 21 \\
\hline 3 & 167 & 13 & 28 & 14 & 137 & 19 & 17 & 31 \\
\hline 5 & 102 & 20 & 31 & 23 & 123 & 17 & 27 & 23 \\
\hline 6 & 162 & 14 & 47 & 16 & 151 & 15 & 7 & 14 \\
\hline 8 & 98 & 8 & 8 & 6 & 101 & 0 & 6 & 10 \\
\hline Sum & 764 & 60 & 147 & 80 & 778 & 73 & 79 & 99 \\
\hline Mean & 5.3 & 5.0 & 8.2 & 7.6 & 7.6 & 6.1 & 6.9 & 8.3 \\
\hline $\operatorname{Max}$ & - & 10 & 15.7 & 11.5 & - & 9.5 & 13.5 & 15.5 \\
\hline
\end{tabular}

The flight room and the hives had at this stage been operated for 11 months without interruption. The column headings describe times of collection and collection intervals. The last 2 rows give the mean number of eggs per hive per hour and the maximum number of eggs per hive per hour, respectively.

The traditional way of collecting eggs of a given age is to confine the queen on a single frame within the hive, and then release the queen and remove the frame after a given time period. Even during the summer, in the bee yard, frequent disturbance of the bees and the queen can have adverse consequences for the egg-laying rate as well as the survival of the queen (personal observation). In addition, the transfer of eggs from the bottom of cells is rather inconvenient. To the best of our knowledge this is the first report of a hive design that allows convenient all-year-round collection of eggs (of specific ages) in a form amenable to laboratory manipulation, while not disturbing the colonies.

\section{ACKNOWLEDGMENTS}

We would like to thank 2 anonymous referees for constructive criticisms, and $\mathrm{K}$ Jenter for providing cheap materials for construction of the hive.

\section{Résumé - Description d'une ruche expérimentale adaptée à la récolte fré-}

quente des œufs. Compte tenu, d'une part, de l'importance de l'abeille tant au niveau commercial qu'en tant que modèle pour l'étude des sociétés d'insectes et en neurobiologie et, d'autre part, que ses œufs peuvent être facilement manipulés en laboratoire (DuPraw, 1967), la rareté des travaux expérimentaux portant sur les œufs et les embryons est très surprenante. II y a certainement plusieurs raisons à cela, mais le manque d'un dispositif adapté de manipulation des œufs et des larves est probablement une des causes principales. Un tel système doit permettre une collecte facile des œufs dans la ruche sans déranger les reines ou les ouvrières. Le présent travail décrit une ruche spécialement adaptée à cet effet, et qui peut être disposée aussi bien en chambre de vol que dans un rucher. Cette ruche consiste en 2 cadres, chacun réalisé à partir de 6 bases de marque Jenter (Karl Jenter, Nurtingen, Allemagne) utilisées habituellement pour l'élevage des reines - qui s'adaptent presque exactement sur un cadre standard norvégien (fig $1 \mathrm{a}, \mathrm{b}$ ). Un corps de ruche est fabriqué pour recevoir les 2 cadres, en respectant un espace pour 
abeilles de $12 \mathrm{~mm}$ (fig 1c, d). Le plancher et le plafond de la ruche sont constitués d'une couche de contre-plaqué de $12 \mathrm{~mm}$ d'épaisseur, et les parois de la ruche de 2 couches (fig 1c, d, f). Deux trous sont percés dans le plafond pour recevoir un flacon de sirop de sucre et une boîte de Petri contenant du pollen (fig 1f). Les différents éléments peuvent être calorifugés (fig $1 \mathrm{c}, \mathrm{f}, \mathrm{h}$ ). Les 90 cellules amovibles en plastique des cadres de Jenter sont disposées sur des plaques d'aluminium (fig 1a) qui sont exactement adaptées aux trous présents dans les cadres. La récolte des œufs est réalisée par prélèvement aux plaques d'aluminium à partir de l'extérieur, sans ouvrir la ruche. Ce dispositif a été testé pendant 11 mois sans problème, en chambre de vol (un dispositif semblable avait été testé au cours des 2 saisons précédentes). Les colonies ont été parfois renforcées avec des abeilles provenant d'autres ruches. Au cours de la saison 1993-1994, 3 reines sur 10 sont mortes ou ont cessé de pondre et ont été remplacées. Le nombre moyen d'œufs récoltés par heure et par colonie est assez constant. À titre d'exemple, le tableau I présente des données de récolte d'œufs pour 6 colonies. C'est la première fois qu'un tel dispositif permettant la récolte d'œufs d'âge connu pendant toute l'année, et dans de bonnes conditions, est décrit.

\section{abeille / œufs / ruche expérimentale / micromanipulation}

\section{Zusammenfassung - Eine Honigbie- nenbeute für das Labor zum häufigen} Sammeln von Eiern (Apis mellifera $\mathrm{L}$ ). Bei der großen Bedeutung der Honigbienen für den Handel, für das Studium des Sozialverhaltens und für neurologische Untersuchungen und der einfachen Zugänglichkeit des Bieneneis für Laborversuche (Dupraw, 1967) ist es erstaunlich, wie wenig Versuche mit Eiern und Larven durchgeführt wurden. Wir glauben, daß ein Haupt- grund sicherlich in der unzureichenden Arbeitsmethode liegt, Bienen, Eier und Larven in der Nähe des Labors zu sammeln. Teil eines solchen Systems müßte eine einfache Methode sein, Eier aus einem Volk zu gewinnen ohne Störung der Königin oder Arbeiterinnen. Hier beschreiben wir einen neuen Beutentyp, der diesen Anforderungen entspricht und der sowohl im Flugraum als auch am Bienenstand benutzt werden kann. Die 'Eisammelbeute' besteht aus 2 Waben, die aus je 6 Jenter-Rähmchen (Karl Jenter, Nürtingen, Germany) zusammengesetzt wird, die sonst bei der Königinnenzucht benutzt werden. Die Jenter-Rähmchen passen fast genau in den norwegischen Standardrahmen (Abb 1a, b). Die Beute ist so gebaut, daß 2 Jenter-Komplexe eine Wabengasse mit dem Bienenabstand ("bee space') von $12 \mathrm{~mm}$ einschließen (Abb 1c, d). Boden und Deckplatte bestehen jeweils aus einer Lage $12 \mathrm{~mm}$ dickem Sperrholz, die jeweiligen Endwände bestehen aus 2 Lagen. Querleisten mit den Maßen $47 \times 17 \mathrm{~mm}$ verbinden die Wände (Abb 1c, d, f). Um eine Zusatzfütterung zu ermöglichen, sind in der Deckplatte 2 Löcher angebracht, eines für eine Futterflasche mit Zuckerwasser, das andere zur Fütterung von Pollenteig in einer umgestülpten Petrischale (Abb 1f). Sowohl die nicht benötigten Jenterwaben als auch Deckplatte und Seitenwände können mit Styroporplatten isoliert werden ( $A b b$ 1d, $f, h$ ). Bei jedem JenterRähmchen werden die 90 herausnehmbaren, aus Plastik bestehenden Zellböden in Löcher auf Aluminiumplatten (Sammelböden, Abb 1a) montiert. Sie müssen genau in die Löcher des Rähmchens passen. Die Gewinnung der Eier kann dann von außen erfolgen, ohne daß das Volk geöffnet werden muß. Die Beutenform, die hier beschreiben wird, ist 11 Monate in einem Flugraum getestet worden und hat sehr gut funktioniert (ein ähnlicher Beutentyp wurde vorher während 2 früherer Saisons benutzt). Die Völker waren meist in der Lage, allein genügend Brut zu 
erzeugen. In einigen Fällen haben wir die Völker mit Bienen aus dem Bienenstand verstärken müssen. Während der Saison 1993-1994 starben 3 von 10 Königinnen bzw sie stellten die Eilage ein. Sie mußten ersetzt werden. Die durchschnittliche Zahl von Eiern, die pro Stunde pro Volk gesammelt werden können, ist ziemlich konstant. Als Beispiel sind in Tabelle I die Daten der Eigewinnung aus 6 Völker am 6 und 7 Juli 1994 gezeigt. Das Volk stand seit September 1993 im Flugraum und die Eilegerate hatte die ganze Zeit etwa auf diesem Niveau oder sogar leicht darüber gestanden. Nach unserer Kenntnis ist dies die erste Beschreibung eines Beutentyps, der das ganze Jahr über erlaubt, datierte Eier in einer Weise zu sammeln, die das Bienenvolk nicht merklich stört.

\section{Honigbiene / Eikollektion / Laborbeute / Flugraum / Mikromanipulation}

\section{REFERENCES}

Doull KM (1976) The effects of different humidities on the hatching of the eggs of honeybees. Apidologie 6, 61-66
DuPraw EJ (1967) The honeybee embryo. In: Methods in Developmental Biology (FH Wilt, NK Wessells, eds), Crowell, New York, USA, 183-217

Jay SC (1964) A bee flight and rearing room. J Apic Res $3,41-44$

Omholt SW, Rishovd S, Hagen A, Elmholdt O, Dalsgard B. From S (1994) Successful production of chimeric honeybee larvae. J Exp Zool (in press)

Peng YSC, Mussen E, Fong A, Montague MA, Tyler T (1992) Effects of chlortetracycline of honey bee worker larvae reared in vitro. $J$ invertebr Pathol 60 , 127-133

Praagh JP van (1972) Towards a controlled environment room suitable for normal colony life of honeybees. I. Description and general observations. J Apic Res 11, 77-87

Praagh JP van (1975) Light-ripple and visual acuity in a climate room for honeybees (Apis mellifera $L$ ). Netherl J Zool 25, 506-515

Rembold H, Lackner B (1981) Rearing of honeybee larvae in vitro: effect of yeast extract on queen differentiation. J Apic Res 20, 165-171

Rembold H, Czoppelt C, Grune M, Lackner B, Pfeffer J, Woker $E$ (1992) Juvenile hormone titers during honeybee embryogenesis and metamorphosis. In: Insect Juvenile Hormone Research-Fundamental and Applied Approaches (B Mauchamp. F Couillaud, JC Baehr, eds) INRA Editions, Paris, France. 37-43

Schnetter M (1934) Morphologische Untersuchungen uber das Differenzierungszentrum in der Embryonalentwicklung der Honigbiene. Z Morph Okol Tiere 29. 114-195 